\title{
Association between prenatal and neonatal factors and occurrence of asthma symptoms in six-year-old children
}

\author{
Associação entre fatores pré-natais e neonatais e ocorrência \\ de sintomas de asma em crianças aos seis anos de idade
}

Leonardo Esmeraldino (https://orcid.org/0000-0002-2910-5346) ${ }^{1}$

Eliane Traebert (https://orcid.org/0000-0001-9667-7216) ${ }^{2}$

Rodrigo Dias Nunes (https://orcid.org/0000-0002-2261-8253) ${ }^{2}$

Jefferson Traebert (https://orcid.org/0000-0002-7389-985X) ${ }^{2}$

${ }^{1}$ Faculdade de Medicina. Universidade do Sul de Santa Catarina. Av. Pedra Branca 25, Cidade Universitária. 88137-270 Palhoça SC Brasil. ${ }^{2}$ Programa de PósGraduação em Ciências da Saúde. Universidade do Sul de Santa Catarina. Palhoça SC Brasil. jefferson. traebert@gmail.com

\begin{abstract}
The objective was to estimate association between prenatal and neonatal factors and asthma symptoms in children at six years of age. A cross-sectional study using secondary data from a cohort study with a sample of 578 children was carried out. Data were analyzed using three levels hierarchical Poisson Regression. Of the 578 children included in the study, 43.4\% (95\% CI 39.4; 47.4) had asthma symptoms. The variables with significantly higher prevalence of symptoms and asthma at six years of age were: male gender, with $5 \%$ higher prevalence $(P R=1.0595 \% C I 1.01$; 1.11) $(p=0.043)$; children of pregnant women presenting infectious diseases with 7\% higher prevalence $(P R=1.07 ; 95 \%$ CI 1.02; 1.13$)(p=$ $0.011)$; children who were not breastfed, with a $12 \%$ higher prevalence $(P R=1.12 ; 95 \%$ CI 1.02; 1.24) $(p=0.022)$ and children with respiratory problems in the first month of life, with a $14 \%$ higher prevalence $(P R=1.14 ; 95 \%$ CI $1.01 ; 1.29)$ $(p=0.033)$. It could be concluded that male gender, time-independent breastfeeding deprivation and respiratory problems in the first month of life were independently associated with asthma symptoms at six years of age. The occurrence of infectious diseases during pregnancy was the only factor with intrauterine physiology that was associated with the occurrence of asthma symptoms at six years of age.

Key words Asthma, Child, Child health
\end{abstract}

Resumo O objetivo foi estimar a associação entre fatores pré-natais e neonatais e sintomas de asma em crianças aos seis anos de idade. Foi realizado um estudo epidemiológico transversal com dados secundários provenientes de estudo de coorte com amostragem de 578 crianças. Os dados foram analisados por meio de regressão de Poisson. Do total de 578 crianças incluídas no estudo, 43,4\% (IC 95\% 39,4; 47,4) apresentavam sintomas de asma. As variáveis com prevalências significativamente maiores de sintomas de asma aos seis anos de idade foram: sexo masculino, com prevalência $5 \%$ maior $(R P=1,05$ IC 95\% 1,$01 ; 1,11)(p=$ $0,043)$; crianças de gestantes portadoras de doenças infecciosas, com prevalência $7 \%$ maior $(R P=1,07$; IC $95 \% 1,02 ; 1,13)(p=0,011)$; crianças que não foram amamentadas, com prevalência $12 \%$ maior $(R P=1,12$; IC 95\% 1,02; 1,24) ( $p=0,022)$, e crianças com problemas respiratórios no primeiro mês de vida, com prevalência $14 \%$ maior ( $R P=$ 1,14; IC 95\% 1,01; 1,29) ( $p=0,033)$. Concluiu-se que sexo masculino, privação de amamentação, independentemente do tempo, e problemas respiratórios no primeiro mês de vida foram associados de forma independente aos sintomas de asma aos seis anos de idade. A ocorrência de doenças infecciosas durante a gravidez foi o único fator fisiológico intra-uterino associado à ocorrência de sintomas de asma aos seis anos de idade.

Palavras-chave Asma, Criança, Saúde da criança 


\section{Introduction}

The prevalence of asthma in children is growing in several Western countries ${ }^{1}$. The increase, in addition to factors related to exposure during child$\operatorname{hood}^{2}$ such as breastfeeding and the occurrence of infections in the first month of life ${ }^{3}$, is also directly related to prenatal conditions ${ }^{4}$ such as maternal obesity ${ }^{5}$ and infections during pregnancy ${ }^{6}$, birth route ${ }^{7}$, APGAR score in the first and fifth minute of life ${ }^{8}$ and prematurity ${ }^{9}$. The prenatal period is essentially linked to the determination of the child's health and can directly influence at the formation of the immune system, an important factor in the pathogenesis of asthma ${ }^{10}$.

According to the Global Initiative for Asthma (GINA), asthma is defined as a chronic inflammatory disease of the airways, which manifests itself through respiratory signs and symptoms such as dyspnea, wheezing, oppression or discomfort of the chest and $\operatorname{cough}^{11}$. The clinical diagnosis is a relatively complex process, based on symptoms or their triggering by irritants or aeroallergen $s^{11}$. Complementary tests such as spirometry and peak expiratory flow complement the diagnosis $^{11}$. Because of this complexity, epidemiological studies use questionnaires that can identify individuals with asthma symptoms ${ }^{12}$. With a view to standardizing and applying greater ease and reliability to these studies, the International Study of Asthma and Allergies in Childhood (ISAAC) was designed to identify children with symptoms and severity of illness from cardinal symptoms. It consists in standardized questionnaires that have been designed and tested for applicability, validity and reproducibility ${ }^{12}$.

On the other hand, the early stages of life represent an opportunity for interventions that guarantee healthy development conditions, which can bring benefits throughout the life cy$\mathrm{cle}^{13}$. The relationship between occurrences in this period and the future development of asthma might disclose factors which support health promotion actions that impact in the determination of asthma.

There are still few studies that explored the approach to factors associated with the occurrence of asthma in childhood ${ }^{3-9}$. In view of this, investigations into factors that influence the occurrence of asthma in childhood, considering prenatal and neonatal factors have become relevant.

The present study aimed to estimate the possible association between prenatal and neonatal factors and the occurrence of asthma symptoms in six-year-old children.

\section{Methods}

A cross-sectional epidemiological design study was carried out using secondary data from a cohort study called Coorte Brasil Sul ${ }^{14}$.

The study that generated the Coorte Brasil Sul ${ }^{14}$ database was carried out in Palhoça, a city in the metropolitan region of Florianópolis, 14 $\mathrm{km}$ from the capital city of Santa Catarina. The estimated population in 2019 was 165,299 with about $95 \%$ living in the urban area ${ }^{15}$. Palhoça has a subtropical climate (humid mesothermal and hot summer), with temperatures between $14^{\circ} \mathrm{C}$ and $27^{\circ} \mathrm{C}$ and annual relative humidity ranging between $82 \%$ and $84 \%$.

The study population was composed of children born in 2009 who were followed until 2015 (when they were seis years old). The calculation of the minimum sample size for the present study followed these parameters: total population of 1,756 children born in 2009 resident and enrolled in schools in the municipality in 2015; anticipated prevalence of asthma symptoms unknown $(\mathrm{p}=50.0 \%)$ and a relative error of $4 \%$, which generated the number of 448 . Since the total number of children in the database with all information needed was 578 , it was decided to include all children with such information in the present study.

The study Coorte Brasil Sul ${ }^{14}$ collected data through interviews containing the ISAAC ${ }^{12}$ questionnaire and information about prenatal and neonatal periods, using a structured form, with children's mothers in their homes, or in their absence, with the main caregiver of the child. Prenatal card and child's health card were consulted to get some information as necessary, but mothers or caregivers were stimulated to remember others.

The team of researchers at Coorte Brasil Sul ${ }^{14}$, including the authors, was responsible for collecting data, together with community health agents from Palhoça, all duly trained to collect data.

In the present study, the dependent variable was the mother's report of asthma symptoms at six years of age according to ISAAC question "Has your child had wheezing or whistling in the chest in the past 12 months?" (yes or no). The independent variables were: child sex; child ethnicity (categorized as Caucasian or non-Caucasian); mother schooling at birth (categorized as up to eight years of study completed or more than eight years); mother age at birth (categorized as less than or equal to 19 , between 20 and 
34, or more than 35 years); number of prenatal visits (categorized as up to six or seven or more); birth route (vaginal or cesarean section); smoking, alcohol intake, and illicit drug use in pregnancy (all, yes or no); occurrence of diabetes, hypertension, and infectious diseases in pregnancy (all, yes or no); preterm birth (categorized as 36 weeks or 37 weeks or more); weight at birth (categorized as until 2,500g or more than 2,500g); birth weight by gestational age - GA (small for GA, suitable for GA or large for GA); APGAR index in the 1st minute and in the 5th minute (categorized in up to seven or above seven); cephalic perimeter (categorized in less than $32 \mathrm{~cm}$ or higher than $36 \mathrm{~cm}$ or between 33 and $35 \mathrm{~cm}$ ); breastfeeding independently of time, occurrence of respiratory problems in the first month; need for intubation in the first month and occurrence of jaundice (all, yes or no).

Data were exported to SPSS 18.0 software from Excel spreadsheets from the original bank, where they were analyzed using Poisson Regression with a robust estimator, hierarchized with the stepwise forward strategy. The prevalence ratios and their respective 95\% confidence intervals were estimated. The hierarchical analysis model proposed for this study is shown in Figure 1, composed of three levels. Sociodemographic variables constituted the first level (child sex and ethnicity, mother's age and schooling at birth), variables related to pregnancy conditions constituted the second level (number of prenatal consultations, way of delivery, smoking, alcohol and illegal drug use during pregnancy, diabetes, hypertension and infectious diseases in pregnancy), and variables related to birth and neonatal conditions constituted the third level (prematu- rity, weight at birth, weight per gestational age, APGAR on the 1th and 5th minute, head circumference, breastfeeding, respiratory problem, need for intubation and jaundice in the first month of life). The use of this model assumes that sociodemographic conditions have the potential to interfere with gestational conditions and these on neonatal conditions. Initially, a bivariate analysis was performed, with all variables of each hierarchical level. It was then elaborated a model with variables of the first level that presented $p<0.20$. In this block, variables that presented $\mathrm{p}<0.05$ were kept. After, variables of the second level were added which in the bivariate analysis presented $p$ $<0.20$. At this moment, variables of the second level that presented $p>0.05$ were removed from the model. Socio-demographic variables that had presented statistical significance in the first stage of the multivariate model were maintained, regardless of the level of significance presented after the introduction of variables related to pregnancy conditions. Thus, a model with two levels was created. Subsequently, variables of the third level were introduced, which in the bivariate analysis presented $p<0.20$. Variables of this third level that presented a $p$ value $<0.05$ were maintained in the model, without removing the variables from the previous levels. Thus, a final model with three levels was obtained. The order of entry of variables in each step obeyed the level of statistical significance observed in the bivariate analysis.

This study respected the ethical principles established by the Brazilian National Health Council Resolution number 466/2012 and has the approval of the Research Ethics Committee of the Universidade do Sul de Santa Catarina.

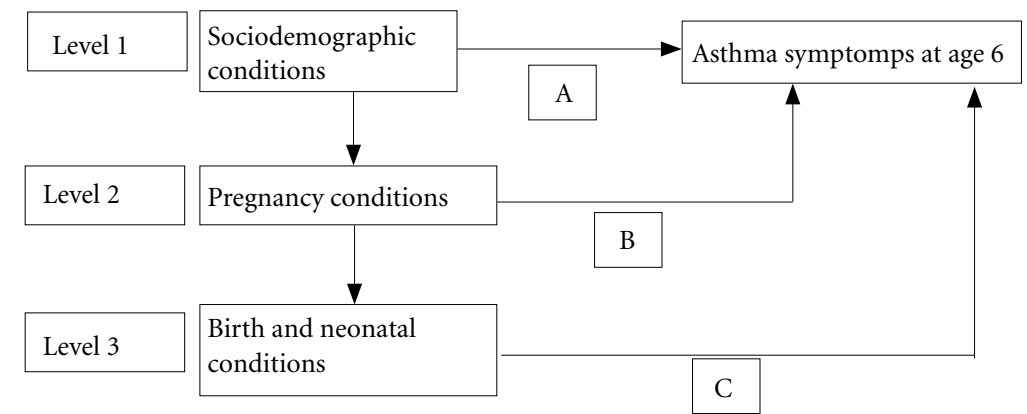

Figure 1. Hierarchical conceptual structure, in blocks, for reporting asthma symptoms at 6 years of age. 
Table 1. Association between variables of the prenatal, perinatal and neonatal periods and asthma symptoms at 6 years of age.

\begin{tabular}{|c|c|c|c|c|c|}
\hline \multirow{2}{*}{ Variables } & \multicolumn{5}{|c|}{ Asthma Symtomps } \\
\hline & $\mathbf{n}$ & $\%$ & $\mathbf{P R}_{c}$ & $95 \%$ CI & p \\
\hline \multicolumn{6}{|l|}{ 1st Level - Socio-Demographic } \\
\hline Child sex & & & & & 0.017 \\
\hline Male & 148 & 48.1 & 1.06 & $1.01 ; 1.12$ & \\
\hline Female & 103 & 38.1 & 1,00 & & \\
\hline Ethnicity of child & & & & & 0.342 \\
\hline Caucasian & 45 & 47.9 & 1,03 & $0.96 ; 1.11$ & \\
\hline Non-Caucasian & 206 & 42.6 & & & \\
\hline \multicolumn{6}{|l|}{ Mother's age at birth } \\
\hline 19 or less & 31 & 44.3 & 1.01 & $0.92 ; 1.08$ & 0.972 \\
\hline Between 20 and 34 & 193 & 44.1 & 1.04 & $0.93 ; 1.15$ & 0.491 \\
\hline 35 or more & 23 & 38.3 & 1.00 & & \\
\hline Mother's schooling at birth & & & & & 0.300 \\
\hline Up to 8 & 116 & 46.8 & 1.03 & $0.97 ; 1.09$ & \\
\hline More than 8 & 121 & 42.3 & 1.00 & & \\
\hline \multicolumn{6}{|l|}{ 2nd Level - Pregnancy conditions } \\
\hline Number of prenatal consultations & & & & & 0.851 \\
\hline Up to 6 & 17 & 41.5 & 0.99 & $0.90 ; 1.09$ & \\
\hline 7 or more & 202 & 43.0 & 1.00 & & \\
\hline Way of delivery & & & & & 0.314 \\
\hline Vaginal & 103 & 41.2 & 1.00 & & \\
\hline Cesarean & 148 & 45.4 & 1.03 & $0.97 ; 1.08$ & \\
\hline Smoking during pregnancy & & & & & 0.057 \\
\hline Yes & 58 & 51.3 & 1.07 & $0.99 ; 1.14$ & \\
\hline No & 190 & 41.3 & 1.00 & & \\
\hline Alcohol in pregnancy & & & & & 0.056 \\
\hline Yes & 21 & 58.3 & 1.11 & $0.99 ; 1.25$ & \\
\hline No & 218 & 42.0 & 1.00 & & \\
\hline Illegal drug use in pregnancy & & & & & 0.023 \\
\hline Yes & 7 & 63.6 & 1.15 & $1.01 ; 1.42$ & \\
\hline No & 240 & 43.0 & 1.00 & & \\
\hline Diabetes in pregnancy & & & & & 0.573 \\
\hline Yes & 34 & 46.6 & 1.02 & $0.95 ; 1.11$ & \\
\hline No & 205 & 43.1 & 1.00 & & \\
\hline Hypertension in pregnancy & & & & & 0.054 \\
\hline Yes & 17 & 60.7 & 1.13 & $1.01 ; 1.29$ & \\
\hline No & 229 & 42.3 & 1.00 & & \\
\hline Infectious diseases in pregnancy & & & & & 0.008 \\
\hline Yes & 116 & 49.2 & 1.12 & $1.03 ; 1.21$ & \\
\hline No & 122 & 37.9 & 1.00 & & \\
\hline
\end{tabular}

\section{Results}

Of the total of 578 children included in the study, $43.4 \%$ (95\% CI $39.4 ; 47.4)$ had asthma symptoms.

The values obtained in the bivariate analysis of the possible risk factors tested at the three levels of the study, in relation to the variable "asthma symptoms at 6 years of age" are shown in Table 1. Male children presented a $6 \%$ higher prevalence $(\mathrm{PR}=1.06 ; 95 \%$ CI $1.01 ; 1.12)(\mathrm{p}=$ 0.017) of asthma symptoms compared to female children. Children whose mothers used illegal drugs during pregnancy had a $15 \%$ higher preva- 
Table 1. Association between variables of the prenatal, perinatal and neonatal periods and asthma symptoms at 6 years of age.

\begin{tabular}{|c|c|c|c|c|c|}
\hline \multirow{2}{*}{ Variables } & \multicolumn{5}{|c|}{ Asthma Symtomps } \\
\hline & $\mathbf{n}$ & $\%$ & $\mathbf{P R}_{c}$ & $95 \% \mathrm{CI}$ & $\mathbf{p}$ \\
\hline \multicolumn{6}{|l|}{ 3rd Level - Birth and neonatal conditions } \\
\hline Prematurity & & & & & 0.301 \\
\hline Up to 37 weeks & 30 & 50.0 & 1.05 & $0.96 ; 1.14$ & \\
\hline 38 weeks or more & 195 & 43.0 & 1.00 & & \\
\hline Weight at birth & & & & & 0.210 \\
\hline Up to $2,500 \mathrm{~g}$ & 13 & 34.2 & 0.94 & $0.85 ; 1.03$ & \\
\hline More than $2,500 \mathrm{~g}$ & 234 & 44.7 & 1.00 & & \\
\hline \multicolumn{6}{|l|}{ Weight per gestational age } \\
\hline Large for gestational age & 32 & 38.1 & 0.95 & $0.89 ; 1.02$ & 0.192 \\
\hline Small for gestational age & 21 & 40.4 & 0.99 & $0.89 ; 1.09$ & 0.791 \\
\hline Appropriate for gestational age & 169 & 45.7 & 1.00 & & \\
\hline APGAR 1th minute & & & & & 0.267 \\
\hline Up to 7 & 23 & 54.8 & 1.06 & $0.95 ; 1.18$ & \\
\hline 8 or more & 191 & 45.8 & 1.00 & & \\
\hline APGAR 5th minute & & & & & 1.000 \\
\hline Up to 7 & 4 & 50.0 & 1.02 & $0.81 ; 1.29$ & \\
\hline 8 or more & 209 & 46.4 & 1.00 & & \\
\hline Head circumference & & & & & 0.586 \\
\hline Less than $32 \mathrm{~cm}$ or bigger than $36 \mathrm{~cm}$ & 45 & 44.6 & 0.98 & $0.91 ; 1.05$ & \\
\hline between 33 and $34 \mathrm{~cm}$ & 161 & 47.6 & 1.00 & & \\
\hline Breastfed & & & & & 0.004 \\
\hline Yes & 214 & 41.3 & 1.00 & & \\
\hline No & 35 & 61.4 & 1.14 & $1.04 ; 1.26$ & \\
\hline Respiratory problem in the first month of life & & & & & 0.006 \\
\hline Yes & 23 & 65.7 & 1.18 & $1.04 ; 1.33$ & \\
\hline No & 226 & 41.9 & 1.00 & & \\
\hline Need for intubation in the first month of life & & & & & 0.183 \\
\hline Yes & 14 & 56.0 & 1.09 & $0.95 ; 1.25$ & \\
\hline No & 233 & 42.7 & 1.00 & & \\
\hline Jaundice & & & & & 0.909 \\
\hline Yes & 49 & 43.0 & 0.99 & $0.93 ; 1.06$ & \\
\hline No & 200 & 43.6 & 1.00 & & \\
\hline
\end{tabular}

lence $(P R=1.15 ; 95 \%$ CI $1.01 ; 1.42)(p=0.023)$. Children of mothers with hypertension during pregnancy had a $13 \%$ higher prevalence $(\mathrm{PR}=$ 1.13 ; 95\% CI $1.01 ; 1.13)(\mathrm{p}=0.054)$ and those with infectious diseases during pregnancy had a $12 \%$ higher prevalence $(\mathrm{PR}=1.12 ; 95 \% \mathrm{CI} 1.03$; 1.21) $(\mathrm{p}=0.008)$. Children who were not breastfed had a $14 \%$ higher prevalence $(\mathrm{PR}=1.14 ; 95 \%$ CI $1.04 ; 1.26)(p=0.006)$. Children with respiratory problems in the first month had a prevalence $18 \%$ higher $(\mathrm{PR}=1.18 ; 95 \%$ CI $1.04 ; 1.33)(\mathrm{p}=$ $0.183)$. Table 2 presents the results of the associa- tion of the level "pregnancy conditions" adjusted by the variables of this level and by the "socio-demographic" level and Table 3 of the level "birth and neonatal conditions" adjusted by the variables of this level and by the "socio-demographic" and "pregnancy conditions" levels.

The final model obtained in the multivariate hierarchical analysis is presented in Table 4 . Variables with significantly higher prevalence of symptoms and asthma at six years of age were presented in Table 4: male gender with 5\% higher prevalence $(\mathrm{PR}=1.0595 \%$ CI $1.01 ; 1.11)(\mathrm{p}$ 
Table 2. Association between variables of the prenatal, perinatal and neonatal periods and asthma symptoms at 6 years of age. Variables of the "pregnancy conditions" level adjusted by the variables of this level and by the variables of the "socio-demographic" level.

\begin{tabular}{|c|c|c|c|}
\hline \multirow{2}{*}{ Variables } & \multicolumn{3}{|c|}{ Asthma Symtopms } \\
\hline & $\mathbf{P R}_{\mathrm{a}}$ & $95 \% \mathrm{CI}$ & p \\
\hline Child sex & & & 0.021 \\
\hline Male & 1.06 & $1.01 ; 1.20$ & \\
\hline Female & 1.00 & & \\
\hline Smoking during pregnancy & & & 0.121 \\
\hline Yes & 1.06 & $0.98 ; 1.14$ & \\
\hline No & 1.00 & & \\
\hline Alcohol in pregnancy & & & 0.277 \\
\hline Yes & 1.06 & $0.95 ; 1.20$ & \\
\hline No & 1.00 & & \\
\hline $\begin{array}{l}\text { Illegal drug use in } \\
\text { pregnancy }\end{array}$ & & & 0.523 \\
\hline Yes & 1.09 & $0.84 ; 1.40$ & \\
\hline No & 1.00 & & \\
\hline $\begin{array}{l}\text { Infectious diseases in } \\
\text { pregnancy }\end{array}$ & & & 0.011 \\
\hline Yes & 1.07 & $1.02 ; 1.13$ & \\
\hline No & 1.00 & & \\
\hline $\begin{array}{l}\mathrm{PRa}=\text { adjusted prevalence ratio. } \\
\text { interval. } \mathrm{p}=\mathrm{p} \text { value obtained by } \\
\text { robust estimator. }\end{array}$ & $\begin{array}{l}\text { CI 95\% } \\
\text { Poisson }\end{array}$ & $\begin{array}{l}=95 \% \text { confic } \\
\text { regression wi }\end{array}$ & \\
\hline
\end{tabular}

$=0.043$ ); children of pregnant women with the occurrence of infectious diseases with $7 \%$ higher prevalence $(\mathrm{PR}=1.07$; CI 95\% 1.02; 1.13) $(\mathrm{p}=$ $0.011)$; children who were not breastfed with a $12 \%$ higher prevalence $(\mathrm{PR}=1.12 ; 95 \%$ CI 1.02; 1.24) $(\mathrm{p}=0.022)$ and children with respiratory problems in the first month of life a $14 \%$ higher prevalence $(\mathrm{PR}=1.14 ; 95 \%$ CI $1.01 ; 1.29)(\mathrm{p}=$ $0.033)$.

\section{Discussion}

The $43.4 \%$ prevalence of asthma symptoms found in this study, using the question "Has your child had wheezing or whistling in the chest in the past 12 months?" is quite high, compared to $22.9 \%$ in children of the same age in Curitiba/ $\mathrm{PR}^{15}$, using the same question as outcome. The International Study of Asthma and Allergies (ISAAC) Phase $3^{16}$, conducted in 20 Brazilian cit-
Table 3. Association between variables of the prenatal, perinatal and neonatal periods and asthma symptoms at 6 years of age. Variables of the "birth and neonatal conditions" level adjusted by the variables of this level and by the "socio-demographic" and "pregnancy conditions" levels.

\begin{tabular}{|c|c|c|c|}
\hline \multirow{2}{*}{ Variables } & \multicolumn{3}{|c|}{ Asthma Symptoms } \\
\hline & $\mathbf{P R}_{\mathrm{a}}$ & $95 \% \mathrm{CI}$ & $\mathbf{p}$ \\
\hline Child sex & & & 0.043 \\
\hline Male & 1.05 & $1.01 ; 1.11$ & \\
\hline Female & 1.00 & & \\
\hline $\begin{array}{l}\text { Smoking during } \\
\text { pregnancy }\end{array}$ & & & 0.134 \\
\hline Yes & 1.05 & $0.98 ; 1.13$ & \\
\hline No & 1.00 & & \\
\hline $\begin{array}{l}\text { Infectious diseases in } \\
\text { pregnancy }\end{array}$ & & & 0.011 \\
\hline Yes & 1.07 & $1.02 ; 1.13$ & \\
\hline No & 1,00 & & \\
\hline Breastfed & & & 0.022 \\
\hline Yes & 1.00 & & \\
\hline No & 1.12 & $1.02 ; 1.24$ & \\
\hline \multicolumn{4}{|l|}{$\begin{array}{l}\text { Respiratory problem in } \\
\text { the first month of life }\end{array}$} \\
\hline Yes & 1.14 & $1.01 ; 1.29$ & 0.033 \\
\hline No & 1.00 & & \\
\hline \multicolumn{4}{|c|}{$\begin{array}{l}\mathrm{PRa}=\text { adjusted prevalence ratio. } \mathrm{CI} 95 \%=95 \% \text { confidence } \\
\text { interval. } \mathrm{p}=\mathrm{p} \text { value obtained by Poisson regression with } \\
\text { robust estimator. }\end{array}$} \\
\hline Source: Author. & & & \\
\hline
\end{tabular}

ies in the same age group, showed prevalence of $24.4 \%$ in Manaus/AM, 29.9\% in Natal/RN and $31.2 \%$ in São Paulo/SP. However, in Itajaí/SC the prevalence was $20.6 \%$. The methods of the present study do not allow pointing out the reasons for the different prevalence, however, it is possible to hypothesize about different socio-demographic characteristics of the populations studied and the time elapsed between studies, which could point to a trend towards an increase in the epidemiological indicators of asthma.

Asthma is a complex disease and has several determining factors that interact with its development, which is why the model of hierarchical analysis of variables was used in this study. After a careful selection of variables and analysis of them, it was found that males, the occurrence of infectious diseases in pregnancy, breast milk deprivation, and the occurrence of respiratory problems in the first month of life were independently associated with a higher prevalence of 
Table 4. Association between variables of the prenatal, perinatal and neonatal periods and asthma symptoms at 6 years of age. Final hierarchical model.

\begin{tabular}{|c|c|c|c|}
\hline \multirow{2}{*}{ Variables } & \multicolumn{3}{|c|}{ Asthma Symptoms } \\
\hline & $\mathbf{P R}_{\mathbf{a}}$ & $95 \% \mathrm{CI}$ & $\mathbf{p}$ \\
\hline \multirow{2}{*}{\multicolumn{4}{|c|}{$\begin{array}{l}\text { 1st Level - Socio- } \\
\text { Demographic }\end{array}$}} \\
\hline & & & \\
\hline \multicolumn{3}{|l|}{ Child sex } & 0.043 \\
\hline Male & 1.05 & $1.01 ; 1.11$ & \\
\hline Female & 1.00 & & \\
\hline \multicolumn{4}{|l|}{$\begin{array}{l}\text { 2nd Level - Pregnancy } \\
\text { Conditions }\end{array}$} \\
\hline \multicolumn{3}{|l|}{$\begin{array}{l}\text { Infectious diseases in } \\
\text { pregnancy }\end{array}$} & 0.011 \\
\hline Yes & 1.07 & $1.02 ; 1.13$ & \\
\hline No & 1.00 & & \\
\hline \multicolumn{4}{|l|}{$\begin{array}{l}\text { 3rd Level - Birth and } \\
\text { Neonatal Conditions }\end{array}$} \\
\hline \multicolumn{3}{|l|}{ Breastfed } & 0.022 \\
\hline Yes & 1.00 & & \\
\hline No & 1.12 & $1.02 ; 1.24$ & \\
\hline \multicolumn{4}{|l|}{$\begin{array}{l}\text { Respiratory problem in } \\
\text { the first month of life }\end{array}$} \\
\hline Yes & 1.14 & $1.01 ; 1.29$ & 0.033 \\
\hline No & 1.00 & & \\
\hline \multicolumn{4}{|c|}{$\begin{array}{l}\mathrm{PRa}=\text { Adjusted prevalence ratio. CI } 95 \%=95 \% \text { confidence } \\
\text { interval. } \mathrm{p}=\mathrm{p} \text { value obtained by Poisson regression with } \\
\text { robust estimator. }\end{array}$} \\
\hline
\end{tabular}

asthma symptoms at age six. Among these variables, respiratory problems in the first month of life presented the highest magnitude of the prevalence of asthma symptoms.

Male children were observed to have a 5\% higher prevalence, which corroborates studies that state that being male is a risk factor during childhood, but that in adolescence, this prevalence tends to reverse ${ }^{17}$. A hypothesis that could justify this alternation of predominance would be the greater tonus and smaller diameter of the airways, which would cause a lower pulmonary flow during childhood in males and adolescence in females ${ }^{18}$. However, this is still a controversial issue, and studies analyzing the real influence of sex on the appearance of asthma symptoms in childhood are lacking.

Regarding the occurrence of infectious diseases during pregnancy, there was a $7 \%$ higher prevalence of asthma in children whose mothers reported some infectious disease during pregnancy. Infectious diseases, by generating in- flammatory reactions during pregnancy, cause an increase in pro-inflammatory cytokines that cross the placental barrier, come into contact with the amniotic fluid, and expose the fetus to these substances ${ }^{6}$. On the other hand, a study points out that some diseases that alter the vaginal flora place children at risk of early microbial pathogenic colonization, since the microbiota of the maternal vaginal canal contributes to the formation of the intestinal flora of the newborn ${ }^{19}$. However, in this study the different pathogens and diseases affecting pregnant women were not investigated.

This study also investigated the association between the deprivation of breast milk in children and the occurrence of asthma. Children who were not breastfed presented a $12 \%$ higher prevalence of asthma symptoms at 6 years of age, compared with those who were breastfed, corroborating a recent study ${ }^{20}$. Breast milk is a solution that contains several immunological compounds, creating a passive immunization through bioactive components, such as IgA and IgG, which facilitate the development of defense mechanisms in children ${ }^{21}$, in addition to containing factors that stimulate the infant's immune system $^{22}$.

With regard to respiratory infections present at the beginning of life, there is evidence that, when they occur in the first month of life, they can constitute one of the main antecedents of asthma in childhood ${ }^{23}$. In this study, a $14 \%$ higher prevalence was observed in children who presented such a condition. Studies differ in explaining the pathophysiological mechanism of respiratory infections in the first month of life in the child's body, which could trigger asthma symptoms. One of the explanations points out that the infections would cause an epithelial lesion of the airways so as to make them more prone to inflammation. However, in children with an appropriate genetic background for asthma, it was not possible to conclude whether lower airway infections would act as a marker for susceptibility to asthma symptoms ${ }^{24}$.

Unexpectedly, smoking during pregnancy was not associated with the occurrence of asthma symptoms in childhood. Several studies ${ }^{25,26}$ have addressed this issue, and some have demonstrated that fetal contact with smoking compromises pulmonary growth, decreasing the diameter of the airways and favoring the appearance of pulmonary diseases. Likewise, in several studies, prematurity has been shown to be an important variable for the occurrence of asthma, due to the 
impairment of lung growth ${ }^{9}$, which did not occur significantly when analyzed together with other variables in this study.

The present study has some limitations. Some variables require more in-depth questions in order to better clarify the real influence of prenatal and neonatal factors on the final outcome, such as whether breastfeeding was exclusively maternal or supplemented, as well as to differentiate infectious agents in lower respiratory tract infections in order to relate the type of infection with the outcome. Because it was a questionnaire applied with the mother or the person responsible for the child, the variables that were not collected in the child's health book may have suffered from memory bias, which could affect the reliability of the data. Similarly, the use of ISAAC does not allow the diagnosis of asthma, but rather the reporting of symptoms. Also, the cross-sectional design used in this study does not allow to study etiologic relationship.

It can be concluded that significant associations were observed among males, infectious diseases in pregnancy, time-independent breast milk deprivation and respiratory problems in the first month of life and asthma symptoms in children at six years of age. New studies are recommended, preferably longitudinal design, in order to better elucidate the determining factors of asthma in children.

\section{Collaborations}

Leonardo Esmeraldino: conception and design, analysis and interpretation of data, review and approval of the final version of the article. Eliane Traebert: conception and design, analysis and interpretation of data, review and approval of the final of the article. Rodrigo Dias Nunes: analysis and interpretation of data, review and approval of the final version of the article. Jefferson Traebert: conception and design, analysis and interpretation of data, review and approval of the final version of the article. 


\section{Funding}

Research partially funded by Prosuc/Capes.

\section{References}

1. Lundbäck B, Backman H, Lötvall J, Rönmark E. Is asthma prevalence still increasing? Expert Rev Respir Med 2016; 10(1):39-51.

2. Wegienka G, Zoratti E, Johnson CC. The role of the early-life environment in the development of allergic disease. Immunol Allergy Clin North Am 2015; 35(1):1-17.

3. Lodge CJ, Tan DJ, Lau MX, Dai X, Tham R, Lowe AJ, Bowatte G, Allen KJ, Dharmage SC. Breastfeeding and asthma and allergies: a systematic review and meta-analysis. Acta Paediatr 2015; 104(467):38-53.

4. Lockett GA, Huoman J, Holloway JW. Does allergy begin in utero? Pediatr Allergy Immunol 2015; 26(5):394-402.

5. Forno E, Young OM, Kumar R, Simhan H, Celedon JC. Maternal obesity in pregnancy, gestational weight gain, and risk of childhood asthma. Pediatrics 2014; 134(2):e535-e546.

6. Collier $\mathrm{CH}$, Risnes K, Norwitz ER, Bracken MB, Illuzzi JL. Maternal infection in pregnancy and risk of asthma in offspring. Matern Child Health J 2013; 17(10):1940-1950.

7. Huang L, Chen Q, Zhao Y, Wang W, Fang F, Bao Y. Is elective cesarean section associated with a higher risk of asthma? A meta-analysis. J Asthma 2015; 52(1):1625.

8. American Academy of Pediatrics, Committee on Fetus and Newborn; American College of Obstetricians and Gynecologists and Committee on Obstetric Practice. The Apgar Score. Pediatrics 2015; 136(4):819-822.

9. Been JV, Lugtenberg MJ, Smets E, van Schayck CP, Kramer BW, Mommers M, Sheikh A. Preterm birth and childhood wheezing disorders: a systematic review and meta-analysis. PLoS Med 2014; 11(1):e1001596.

10. Holt PG, Upham JW, Sly PD. Contemporaneous maturation of immunologic and respiratory functions during early childhood: implications for development of asthma prevention strategies. J Allergy Clin Immunol 2005; 116(1):16-24.

11. Global Initiative for Asthma - GINA. Global Strategy for Asthma Management and Prevention 2017. [cited 2019 Aug 24]. Available from: http://www.ginasthma. org/local/uploads/files/GINA_Report_2015_Aug11. pdf

12. Asher MI, Keil U, Anderson HR, Beasley R, Crane J, Martinez F, Mitchell EA, Pearce N, Sibbald B, Stewart AW. International Study of Asthma and Allergies in Childhood (ISAAC): rationale and methods. Eur Respir J 1995; 8(3):483-491.

13. Cunha AJLA, Leite AJM, Almeida ISS. Atuação do pediatra nos primeiros mil dias da criança: a busca pela nutrição e desenvolvimento saudáveis. J. Pediatr (Rio J) 2015; 91(6): S44-S51.

14. Traebert J, Lunardelli SE, Martins LGT, Santos K, Nunes RD, Lunardelli AN, Traebert E. Methodological description and preliminary results of a cohort study on the influence of the first 1,000 days of life on the children's future health. An Acad Bras Cienc 2018; 90(3):3105-3114.

15. Ferrari FP, Rosário Filho NA, Ribas LFO, Callefe LG. Prevalência de Asma em escolares de Curitiba - projeto ISSAC (International Study of Asthma and Allergies in Childhood). J Pediatr (Rio J) 1998; 74(4):299-305. 
16. Solé D, Wandalsen GF, Camelo-Nunes IC, Naspitz CK, ISAAC - Grupo Brasileiro. Prevalence of symptoms of asthma, rhinitis, and atopic eczema among Brazilian children and adolescents identified by the International Study of Asthma and Allergies in Childhood (ISAAC), Phase 3. J Pediatr (Rio J) 2006; 82(5):341-346.

17. Instituto Brasileiro de Geografia e Estatística (IBGE). Santa Catarina. Palhoça. Estimativa da população; 2019. [cited 2019 Oct 4]. Available from: www.cidades.ibge.gov.br

18. Boechat J. Prevalência e gravidade de sintomas relacionados à asma em escolares e adolescentes no município de Duque de Caxias, Rio de Janeiro. J Bras Pneumol 2005; 31(2):111-117.

19. Luna MFG, Fisher GB, Luna JRG, Silva MGC, Almeida PC, Chiesa D. Prevalência de asma em escolares de 6 e 7 anos de idade na cidade de Fortaleza, Brasil. Braz J Allergy Immunol 2013; 1(5):279-285.

20. Keski-Nisula L, Katila ML, Remes S, Heinonen S, Pekkanen J. Intrauterine bacterial growth at birth and risk of asthma and allergic sensitization among offspring at the age of 15 to 17 years. J Allergy Clin Immunol 2009; 123(6):1305-1311.

21. Gomes MM. Aleitamento materno e a prevenção da doença alérgica: uma revisão baseada na evidência. Rev Port Med Geral Fam 2019; 35(3):203-209.

22. Hoppu U, Kalliomaki M, Laiho K, Isolauri E. Breast milk-immunomodulatory signals against allergic diseases. Allergy 2001; 56(Suppl. 67):23-26.

23. Friedman NJ, Zeiger RS. The role of breast-feeding in the development of allergies and asthma. J Allergy Clin Immunol 2005; 115(6):1238-1248.

24. Sorio G, Edelmuth S, Utiyama T, Almeida J. Asma: perfil da população infantil atendida na UBS Vitória Régia, Sorocaba/SP. Medicina 2017; 50(2):91-101.

25. Beigelman A, Bacharier LB. Early-life respiratory infections and asthma development: role in disease pathogenesis and potential targets for disease prevention. Curr Opin Allergy Clin Immunol 2016;16(2):172178.

26. Machado MB, Borges JPA. Complicações apresentadas por recém-nascidos de mães tabagistas no período neonatal. Rev Enferm Atenção Saude 2017; 6(2):179187.

Article submitted 03/06/2020

Approved 29/03/2021

Final version submitted 31/03/2021

Chief editors: Romeu Gomes, Antônio Augusto Moura da Silva 